Indonesian Journal of EFL and Linguistics

Vol. 5 No. 2, 2020

eISSN: 2503-4197, pISSN: 2527-5070

www. indonesian-efl-journal.org

\title{
Survival Skills in Digital Era: An Integration of Digital Literacy into EFL Classroom
}

\author{
Nurul Alfia \\ Universitas Sebelas Maret \\ e-mail: nurulalfia038@gmail.com \\ Sumardi \\ Universitas Sebelas Maret \\ e-mail: sumardi74@staff.uns.ac.id; \\ Diah Kristina \\ Universitas Sebelas Maret \\ e-mail: diahkristina@ staff.uns.ac.id
}

\begin{abstract}
:
The development of digital technology has made digital natives encounter situations that require survival skills to face intense competition in the digital age. This case study investigates how students integrate their digital literacy in the EFL classroom and what components of digital literacy are frequently integrated by the students. Three students from a senior high school in Surakarta were recruited purposively. A case study design was used in this research study. The results of interviews and observations revealed that in practice, students integrate digital literacy in every activity related to the use of the internet and digital tools. Students tended to integrate digital literacy according to the activity and objective to be achieved, ranging from searching for and understanding information to make new products. Meanwhile, digital literacy frequently integrated by the students was photo-visual literacy, information literacy, reproduction literacy, and real-time thinking literacy.
\end{abstract}

Keywords: digital era, digital literacy, survival skills

Indonesian Journal of EFL and Linguistics, 5(2), 2020 


\section{INTRODUCTION}

Recently, digital technology has become an integrated part of every educational field, including language learning. The massive expansion of digital technology requires special skills that can help students survive in the 21st Century and digital age competition. These 21st-century skills consist of critical thinking, creativity, communication, teamwork, and ICT and information literacy (Thijs, Fisser, \& van der Hoeven, 2014 in Bekker et al., 2015)). Furthermore, Bekker et al., (2015) added that digital literacy is one of the skills that must be possessed in the 21st Century. Digital literacy can be defined as the ability to understand, interpret, communicate, and create information obtained through all digital sources. Digital literacy takes a vital part to compensate for the transformation of the ages because it can be used as a set of skills for an understanding of the web and search engine.

Digital literacy takes a role as a filter of information. By mastering digital literacy, students are assumed to have the competence to understand that not all information is presented on the internet are trusted; thus, students can distinguish which information is reliable and which information need to be rechecked. In the educational environment, digital literacy is considered a set of skills that claimed to be able to improve students' higher-order thinking skills such as analysis, cooperation, and creation, to bridge students to access more accurate and credible information quickly and easily. Digital literacy also claimed to be able to prepare students for the fourth industrial revolution era (Blois, 2013, as cited in Sadaf \& Johnson, 2017)). With the increasing presence of technology in everyday life, many scholars argue students have to possess digital literacy.

Furthermore, today's high school students are categorized as digital natives; they were born and grew up surrounded by digital devices such as computers and the internet from an early age (Prensky, 2001).Accessing the internet to social media, digital video, online games, online music players, and instant messages is regularly done. Since they spend most of their time struggling and interacting with digital devices, they are assumed being familiar and able to master digital tools and becoming digitally literate to support digital learning better than prior generations do; thus, learning with digital technology can promote students' digital literacy (Perdana et al., 2019). In line with this, Porat et al., (2018) claimed that digital natives, whose lives are surrounded by digital technology and connected with social media, will naturally build digital literacy skills. In other words, the more often students interact with digital technology, the higher the ability of students' digital literacy.

Realizing the importance of having digital literacy competencies for students, Bekker et al., (2015) developed digital literacy learning through design-based learning tools in schools. Their research objectives focus on exploring devices supporting children's learning in digital literacy and design thinking. This research also explains that learning with a Reflective Design-Based Learning (RDBL) framework can help teach digital literacy and design thinking to digital native students. RDBL is considered able 
to describe the challenges in developing integrated processes that can be carried out in schools, adapting to teachers' abilities, appealing to children, and adjusting to the knowledge presented in the material, which supports teaching-learning objectives as requested by the government. Another effort to develop students' digital literacy competence is by implementing digital literacy practice in the classroom. Akayoğlu et al., (2020) investigated digital literacy practices of Turkish pre-service EFL teachers, including how pre-service teachers (PTs) define digital literacy, what kind of tools they used, and for which purposes they preferred to use digital tools. By using a qualitative design, this study revealed that the concept of digital literacy consists of many levels, from knowledge to use and critical, creative, and collaborative use. Furthermore, the development of PTs' digital literacy levels was influenced by the university lecturers. Third, it was concluded that PTs tend to use social media platforms heavily for various purposes; however, the study identified a need for further guidance in supporting PTs' use of these platforms for their professional development.

The school recognized that both teachers and students must be the same at mastering digital capabilities as one of the institutions that play an essential role in developing students' digital literacy (Kurnia \& Astuti, 2017). In Indonesia, Kurniawati et al., (2018) investigated the praxis of digital literacy in the EFL classroom by comparing digital immigrant and digital native teachers in Indonesia using ACOT's (Apple Classroom of Tomorrow) framework. The results showed that digital-immigrant and digital-native teachers were at the level of adapting in terms of digital literacy, but digital-native teachers look more adept at applying digital media; this was reflected in the use of digital technology media in learning English. Furthermore, students positively welcomed utilizing digital technology as an English learning media to make the classroom atmosphere more pleasant and comprehensive. In regards, Puspito, (2017) explored the implementation of digital literacy in the school literacy movement. From the research, it can be seen that the literacy activities have shifted from understanding the information obtained by reading and writing in printed media to the events of understanding, interpreting, communicating, and making information collected from digital media. For example, the teacher took the initiative to involve students in using Smartphones to find and access sites (Google) that could help them find the information related to the subject materials. Upload the answer through the quipper application or Whatsapp (WA) group. This activity is done to reduce paper usage and efforts to prevent students from being distracted by accessing online games or sites that are not age-appropriate.

Meanwhile, (Solikhati \& Pratolo, 2019) investigated the implementation of digital literacy in EFL learning using a descriptive qualitative method. The result revealed that the application of digital literacy was limited to the use of digital devices, such as computers (to deliver English materials) and smartphones. This refers to the teachers' understanding of digital literacy, which is an ability to read and understand the information presented visually through digital technology devices. 
Although there is quite a lot of previous research that addresses the implementation and practice of digital literacy, most researchers only describe how digital literacy is applied in teaching rather than learning in the classroom. This can be seen from several studies that focus on how teachers imply digital literacy in the classroom. To the author's knowledge, research on how students integrate digital literacy in the context of learning English is still limited. The need to practice digital literacy to adolescents is vital because adolescents are considered the most vulnerable group to receive the most dangerous effects of digital media. This is what underlies the authors to raise the problem:

1. How are students integrating digital literacy in the EFL classroom?

2. What digital literacy competencies are students often praxis in the EFL classroom?

\section{LITERATURE REVIEW}

\subsection{Digital Literacy}

The concept of digital literacy was initiated first by Gilster (1997) as a set of abilities to understand and use information obtained from various digital sources. Gilster suggests that digital literacy is more than the ability to operate digital devices but instead emphasizes users to think critically in processing information presented digitally. Meanwhile, Martin (2005) states that digital literacy is the ability, attitude, and awareness of an individual in utilizing digital devices to identify, access, manage, integrate, evaluate, analyze, and process information obtained from the digital tools, build new knowledge, create media expressions, and communicate with others appropriately. Regarding this, Eshet-Alkalai (2012) added that digital literacy is the ability of individuals to operate and use digital devices and includes the cognitive, motor, sociological, and emotional skills needed to function effectively. In short, digital literacy can be defined as the ability to use, understand, interpret, communicate, and create information obtained through all digital sources by involving sociological and emotional abilities. The version of digital literacy proposed by Eshet-Alkalai (2012) is assumed to support students in accessing and exchanging information; discover, understand, analyze, assess, create, and disseminate information appropriate for users.

\subsection{Competence of Digital Literacy}

In the digital era, digital literacy skills have become a 'survival skill' - a key that helps individuals to work naturally in performing complex digital tasks (Eshet-Alkalai, 2012). Slightly different from previous research, the framework that was conceived by (Eshet, 2004) integrates cognitive abilities, thinking strategies, and mindset in the use of technology. The cognitive abilities thought processes and thought patterns are: Photo-visual thinking skill; this skill refers to the ability to read the message of information presented through pictures, icons, graphics, charts, etc. The photo-visual thinking students are assumed to have an excellent visual memory and intense intuitive-associative thinking that are useful in understanding visual messages 
(Nielsen, 1993 in Eshet-Alkalai, 2012)). Reproduction digital skills, this skill are illustrated as the ability to create a new interpretation by combining the pre-existed information. Students who have these skills are considered to have excellent synthetic and multidimensional thinking skills, and this ability will help them make new interpretations of data.

Another skill is branching digital skills. This skill is a development of Hypermedia technology -one of the core competencies proposed by Gilster (1997)- this skill refers to the ability to synthesize knowledge and understand information through non-linear navigation in a hypertensive environment maintain focus without being "lost" in cyberspace. By having this competence, students will have good metaphoric thinking and the ability to build mental models, concept maps, and other forms of abstract representation of the web structure. This competence helps them to resolve disorientation problems in hypermedia environments. Information digital skills, this ability take part as a filter in searching for information. The students who possess these skills are able to judge and analyze the truth of information critically and distinguish the hoax information easily; thus, the spread of false information can be stopped. Socio-emotional digital skills, this skill involve students' emotional and sociological aspects of working in cyberspace. Sociological and emotional skills are used to understand the rules and survive the obstacles and risks that await those in cyberspace. By owning this ability, students will be more careful not to share personal information about themselves, friends, or family in cyberspace. The last skill proposed by Eshet is real-time thinking skill; this described the ability to effectively process stimuli and information simultaneously at high rapid in a digital environment, such as learning simulations, online games, or synchronous online teaching and learning.

\subsection{Digital literacy practice in language education}

According to Thorne \& Reinhardt (2008), one approach that might suit students' literacy needs through the language curriculum is to involve students with activities called 'bridging activities.' Students are asked to find, explore, and analyze information obtained from the web and other technologies such as instant messaging, blogs, Wikipedia, remixing, and multiplayer online games in this activity. In regards to this, Hafner (2014) suggest that digital literacy can be implemented within the existing language curriculum by involving digital technology in learning activities. For example, in addition to collecting assignments in the conventional form, students can be asked to submit their works via email, create a specific language project as a multimodal scientific documentary, and then upload and share it with the public on their YouTube channel.

In addition, Dudeney and Hockly (2016) in (arr \& Murray (2016) argue that students can acquire digital literacy as part of language learning through activities and assignments that combine technology. However, the teachers can only ensure students are effectively involved with digital literacy skills, given that students themselves are digitally literate. Therefore, they noted that teachers should operate technological 
devices, understand technology's functions, and associate technology in language learning.

\section{RESEARCH METHODOLOGY}

\subsection{Participants}

This research was belonging to a qualitative case study approach. Classroom observation and semi-structured interviews were conducted in one of the senior high schools in Surakarta. This research conducted purposive sampling and recruited three senior high school students in eleventh grade (around 16 years old) as participants and has diverse backgrounds. Thus, these young learners are considered "digital natives" (Prensky, 2001) and as such, on average, are expected to have relatively high skills in the use of digital technology. All participants in the class were allowed to bring a smartphone or laptop (if needed) connected to the internet network, whether connected to the WiFi provided by the school or using personal mobile data. In addition, all participants were active internet users who use it as a media to connect with others (social media) or as a media to help them learn English.

\subsection{Instruments}

Based on Creswell (2007) there are several techniques of data collection; observation, interviews, audiovisual materials, questionnaires, and documents. In this case, the researcher utilized classroom observation to find-out how students implied digital literacy in the EFL classroom and held an interview with the teacher and several students as triangulation data in one of the Senior High School in Surakarta.

\subsection{Data Analysis Procedures}

According to Miles et al., (2014) there are three steps to analyze data, collecting the data, condensing the data, displaying the data, and drawing conclusions. In the beginning, the data relating to the research were processed, while other findings that were not related were discarded. In this study, the processed data was data obtained from observation and semi-structured interviews about how students apply digital literacy and the extent to which they imply it in the EFL classroom. Data collected from observations and interviews were condensed; by transcript, coded, and generated, the data was displayed descriptively. In the end, the conclusion was drawn as the final result of the study.

\section{FINDINGS}

\subsection{The integration of digital literacy in the EFL classroom}

The observations made at one of the senior high schools in Surakarta revealed that the teachers often use technology tools to complete their work, such as using personal computers to design lesson plans, utilizing PowerPoints and projectors to facilitate the transfer of learning materials, empowering the internet as one source of additional learning information, using YouTube as an instructional media, utilizing specific applications and sites that are considered capable of promoting students' English proficiency, such as TED-Ed. In addition, teachers also often invite students to 
participate in using social media to exchange information and discuss actively. In this activity, students show quite keen interest. Students pay close attention to the material reflected through the projector and the examples obtained through the internet.

According to some students, the internet was utilized to interact with others (the use of social media) and learn English. Accessing digital/online translators, YouTube, or 'googling' additional information related to English material they do not understand well.

"Personally, I often use digital technology, both to support learning or just social interaction through the internet. For the sake of learning, especially English, I often use online translation such as Google Translate to make it easier for me to find the meaning of English vocabulary that I find unfamiliar and difficult".

For some students, the internet was not only a place to find information. Still, it could also be a facilitator to influence their English skills, such as mastering vocabularies, listening, speaking, writing, and even reading skills by accessing YouTube, podcasts, and sometimes they watched English video blog (vlog).

"Usually, I use the internet to access English vlog on YouTube, a podcast on Spotify. It quite promotes my ability to speak English, especially in pronunciation. I know how to pronounce a word correctly, enrich my vocabularies, and so on."

In another perspective, the internet was often used to help complete the teacher's assignments due to its effectiveness and efficiency. As one student said that the internet offered complete and varied information compared to books; moreover, information can be obtained quickly to save time.

Because students used the internet to find information and facilitators to improve their English skills, students have to evaluate a website, youtube channel, or a trusted podcast account. To overcome the issue of spreading inaccurate information about the subject material they were searching for, they had their strategies to deny it. One student stated that comparing information from several sources could help her to find reliable and valid data.

One student mentioned that she tended to collect information from trusted websites such as one of the well-known English courses said, "I prefer to find information about learning from trusted websites, such as English First (EF)." This student believed that the course's website contains accurate and trustworthy information, given the excellent image, and has expert and experienced tutors. However, another student said that he always relied on the website recommended by the teacher. This student believed that the site recommended by the teacher is a trusted website that contains valid and reliable information. Meanwhile, for YouTube and podcast channels, they agree that channels managed by native speakers with educational or entertaining content can help them improve their English skills. 
The use of the internet was to search for additional information, improve English language skills, or complete tasks but was also used to create a new product. Based on observations made by researchers, when the teacher asked students to make a brochure with an agreed theme, most of the students were using the Canva application. The rest groups of students were utilizing CorelDraw to create a brochure. The Canva and CorelDraw applications provide various templates that can be edited according to the purpose and creativity; easy-friendly use was also one of the advantages of these two applications. By utilizing these two applications and the internet, students did not have to manually drew their brochures; complete information and variations of images available on the internet made it easier for students to complete their assignments.

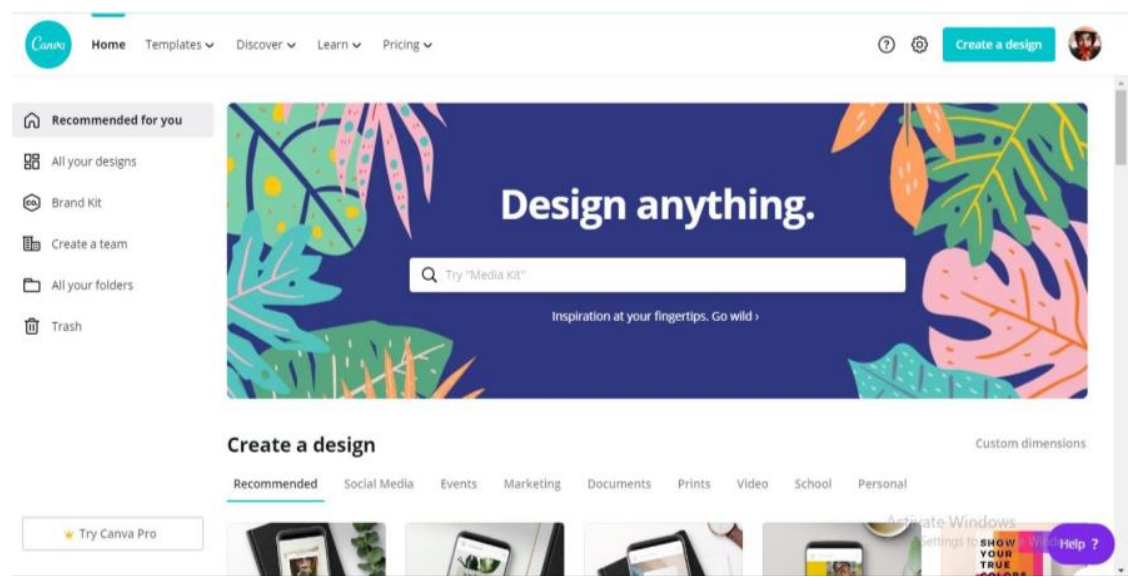

Figure 1. The initial display of the Canva application Source: https://www.canva.com/

In online applications, the use of icons or images for toolbar rather than text to associate specific commands is very dominant, as well as the Canva application (Figure 1); home icon for the back to the first-page, gear icon for settings, question mark icon for help and so on. For initial appearance, the Canva application was still equipped with text to explain the purpose of a symbol. This certainly made it easier for users who were first using this application. However, when going to the editing stage, users were faced with a display that was dominated by icons (Figure 2).

To use applications that were dominated by symbols and images, students must have expertise in reading and interpreting information presented in illustrations; this skill was known as photo-visual literacy (Eshet-Alkalai, 2012). 


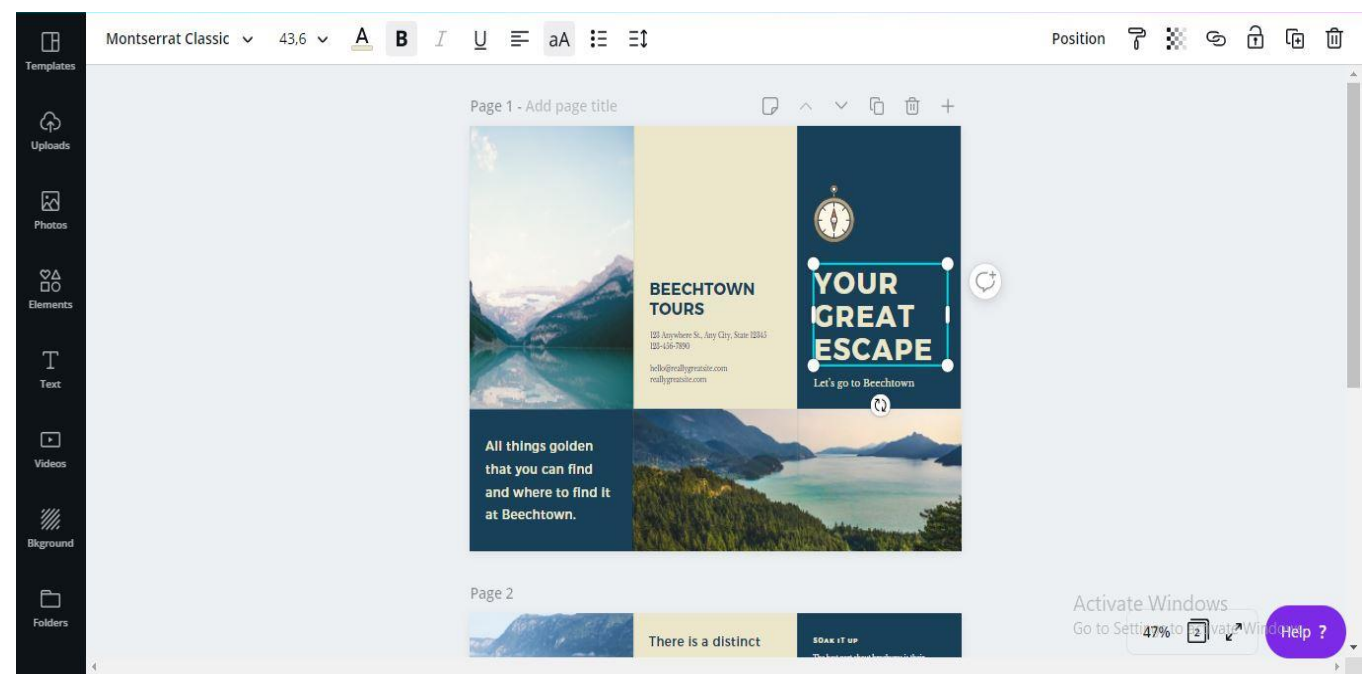

Figure 2. Canva templates and editing

Source: https://www.canva.com/design/

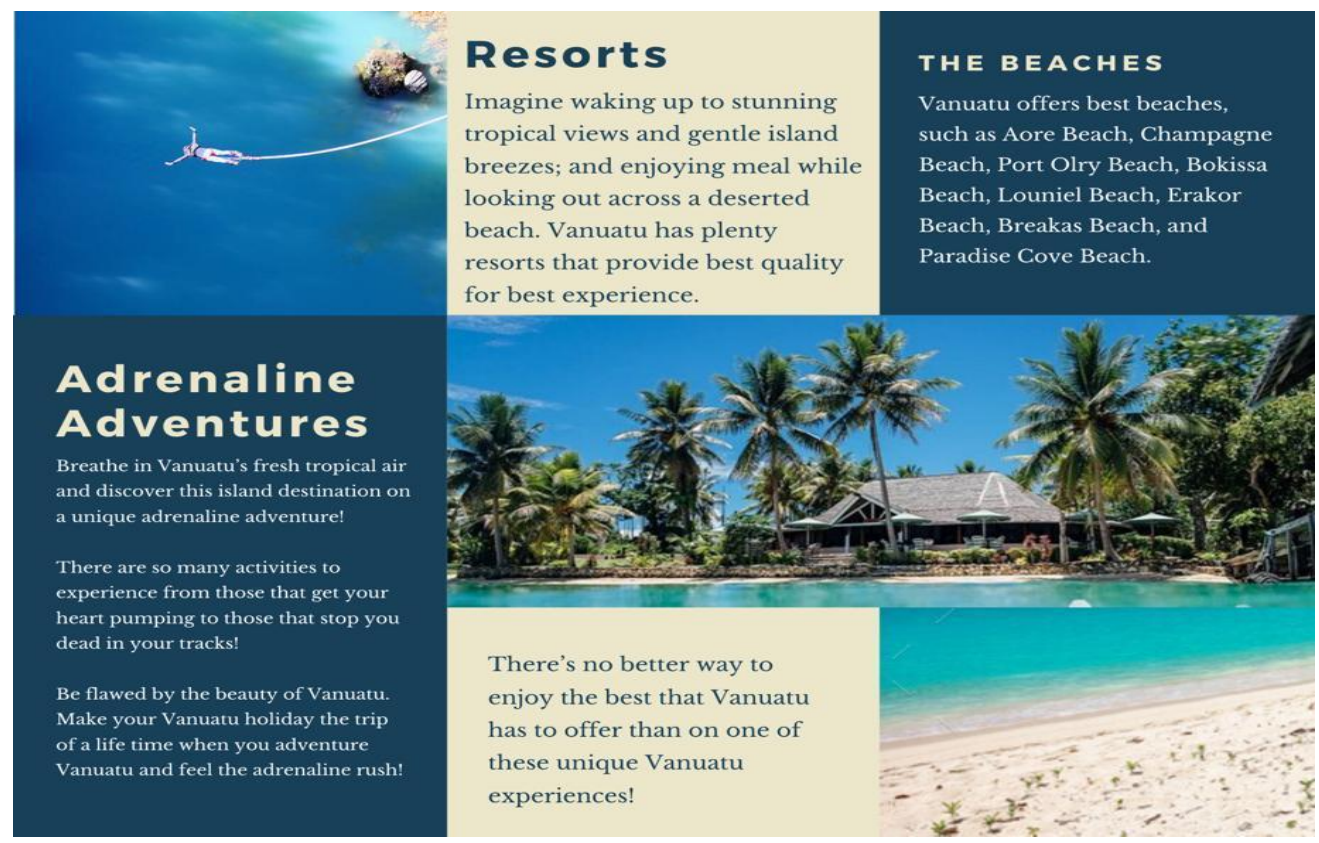

Figure 3 Students' brochure design

Source: Author's document

In the end, students were able to produce a product using online. In the end, students created products using an online application that was equipped with relevant and exciting images accompanied by additional information related to the intended image (Figure 3). Students can use the Canva and CorelDraw applications to produce brochures, proving that students have photo-visual literacy skills and reproducing skills. 
Meanwhile, in terms of literacy of real-time thinking based on observations, it can be seen that students were very focused on their work. However, sometimes they were distracted by other images that emerge, students can quickly refocus on assignments. This observation result was supported by student interviews, which state that they tend to ignore pop-up advertisements that appear when searching for information but cannot yet completely ignore the text messages they receive. Their focus was often divided when they receive text messages (SMS, WA, or Direct Message), but they will refocus on the initial task.

"Yes, pop-up ads often appear, but I often ignore them. I just skip because it was annoying."

Similarly, another student said, "I can easily ignore pop-up ads, but sometimes I get distracted by the incoming message (WhatsApp) notification. I often choose to reply to the messages first, then continue to do my work again."

\subsection{Competencies of digital literacy that are frequently integrated by students in EFL classroom}

The results of observations in teaching and learning activities will be used as a reference to find out information about digital literacy elements that are often integrated by students in using digital tools and the internet. The table below illustrates student activities in teaching and learning and the digital aspects of literacy that emerge through these activities.

Table: 1 Observation result

\begin{tabular}{|c|c|c|c|}
\hline \multirow{2}{*}{ Main Activities } & \multicolumn{2}{|c|}{ Thematic Coding } & \multirow{2}{*}{$\begin{array}{l}\text { Theory } \\
\text { Coding }\end{array}$} \\
\hline & Theme & Sub-Theme & \\
\hline $\begin{array}{l}\text { The teacher displays a sample of brochures in } \\
\text { the form of pictures through the projector } \\
\text { screen. Then students were asked to understand } \\
\text { the information contained in the brochure }\end{array}$ & Practice & Photo-visual & $\begin{array}{l}\text { (Eshet- } \\
\text { Alkalai, } \\
\text { 2012) }\end{array}$ \\
\hline $\begin{array}{l}\text { The teacher showed another example of the } \\
\text { brochure in the form of a picture and displayed } \\
\text { it through the projector screen. Then the } \\
\text { students were asked to understand the } \\
\text { information contained in the brochure and } \\
\text { compared the information obtained with the } \\
\text { previous brochure }\end{array}$ & Practice & Photo-visual & $\begin{array}{l}\text { (Eshet- } \\
\text { Alkalai, } \\
\text { 2012) }\end{array}$ \\
\hline $\begin{array}{l}\text { Students were asked to search for examples of } \\
\text { other brochures via the internet, and gather } \\
\text { information from these brochures }\end{array}$ & Practice & $\begin{array}{l}\text { Photo-visual } \\
\& \text { Information }\end{array}$ & $\begin{array}{l}\text { (Eshet- } \\
\text { Alkalai, } \\
\text { 2012) }\end{array}$ \\
\hline $\begin{array}{l}\text { Students searched for brochure references from } \\
\text { the internet by using their smartphone }\end{array}$ & Practice & $\begin{array}{l}\text { Photo-visual } \\
\& \text { Information }\end{array}$ & $\begin{array}{l}\text { (Eshet- } \\
\text { Alkalai, } \\
\text { 2012) }\end{array}$ \\
\hline
\end{tabular}




\begin{tabular}{|c|c|c|c|}
\hline $\begin{array}{l}\text { Students were asked to realize their brochure } \\
\text { design using the Canva application }\end{array}$ & Practice & $\begin{array}{l}\text { Photo-visual, } \\
\text { Reproduction }\end{array}$ & $\begin{array}{l}\text { (Eshet- } \\
\text { Alkalai, } \\
\text { 2012) }\end{array}$ \\
\hline $\begin{array}{l}\text { Students presented the results of their brochures } \\
\text { in the form of images displayed through the } \\
\text { projector screen }\end{array}$ & Practice & $\begin{array}{l}\text { Photo-visual, } \\
\text { Information }\end{array}$ & $\begin{array}{l}\text { (Eshet- } \\
\text { Alkalai, } \\
\text { 2012) }\end{array}$ \\
\hline $\begin{array}{l}\text { Students gave criticism, suggestions, comments, } \\
\text { from brochures that have been made and } \\
\text { presented by other groups }\end{array}$ & Practice & $\begin{array}{l}\text { Photo-visual, } \\
\text { Information }\end{array}$ & $\begin{array}{l}\text { (Eshet- } \\
\text { Alkalai, } \\
\text { 2012) }\end{array}$ \\
\hline $\begin{array}{l}\text { The teacher explained the material by utilizing } \\
\text { the PowerPoint and LCD projector as a media } \\
\text { to convey the material. Students paid attention } \\
\text { to the information carried by the teacher }\end{array}$ & Practice & Information & $\begin{array}{l}\text { (Eshet- } \\
\text { Alkalai, } \\
\text { 2012) }\end{array}$ \\
\hline $\begin{array}{l}\text { Students look up the meaning of difficult words } \\
\text { by accessing an online dictionary }\end{array}$ & Practice & Information & $\begin{array}{l}\text { (Eshet- } \\
\text { Alkalai, } \\
\text { 2012) }\end{array}$ \\
\hline $\begin{array}{l}\text { Students determined themes using the internet } \\
\text { as a source of reference and inspiration }\end{array}$ & Practice & Information & $\begin{array}{l}\text { (Eshet- } \\
\text { Alkalai, } \\
\text { 2012) }\end{array}$ \\
\hline $\begin{array}{l}\text { Students opened several online sites to look at } \\
\text { some sample brochures, found information and } \\
\text { images that were appropriate }\end{array}$ & Practice & Information & $\begin{array}{l}\text { (Eshet- } \\
\text { Alkalai, } \\
\text { 2012) }\end{array}$ \\
\hline $\begin{array}{l}\text { Students paid attention to the information } \\
\text { conveyed by the group presentations in the form } \\
\text { of images through a projector }\end{array}$ & Practice & Information & $\begin{array}{l}\text { (Eshet- } \\
\text { Alkalai, } \\
\text { 2012) }\end{array}$ \\
\hline
\end{tabular}

As the observations show how students integrate digital literacy, it was reflected in their activities. Digital devices provided by schools were utilized by teachers to convey learning very well. Facilities that have been provided by schools such as; LCD projector, multimedia devices, $\mathrm{WiFi}$, etc., are used to facilitate teachers and students in teaching and learning activities. By utilizing ICT, students get more opportunities to integrate digital literacy. This can be seen from several activities carried out by students, such as paid attention to the subject materials of the presentation slides, looked for additional information about learning material on the internet, and created a project utilizing online applications to present it in front of the class in digital form, etc. The information available was not only in the form of text but also in the way of images. Besides, to access the internet and use online applications that are dominated by icons or pictures, students need the ability to interpret all of the information. In this case, students' photo-visual and information skills play an active role in processing all the information and determining the credible information obtained

The activities held showed that the competencies of digital literacy frequently integrated by the students are photo-visual literacy and information literacy. On the 
other hand, students can create a new work by combining information already available on the internet and utilizing templates that are already available in online applications (in this case, creating brochures with the Canva and CorelDraw applications) showed the reproduction literacy capabilities of students.

\section{DISCUSSION}

Since digital literacy is useful to assist students in filtering information obtained through digital media, thus digital literacy is a skill that must be mastered by the digital native in the 21st Century (Bekker et al., 2015). In these conditions, educators and learners need to master technology and use it in learning. This study aimed to explore how the students integrate digital literacy and what kind of digital literacy competencies are frequently integrated by students in the classroom.

The observation result revealed that teachers and students were actively utilizing digital technology in learning, especially in learning English, to facilitate teaching and learning activities, delivered material, searching for additional information, exchanged information, and created digital-based projects. Meyer suggests that teachers use the appropriate technology as a communication tool that helps in their classes (Meyer, 2002). In addition to utilizing available information technology, teachers must also integrate students with fun and interactive learning processes. It is undeniable that digital technology's presence and use can benefit if adapted in an educational context.

In this study, it was revealed that students integrated digital literacy into learning activities. In practice, students integrate digital literacy along with the use of digital technology in teaching and learning activities. Students use digital devices as instructional media to find information about the subject material, analyzing and employing the information, and producing a product through digital tools. The transition from conventional media use to digital technology is categorized as the adaptation of digital literacy (Kurniawati et al., 2018). This finding is in line with research conducted by Liansari \& Nuroh which reports that the application of digital literacy in the Muhammadiyah University of Sidoarjo is in the form of a transition from the use of conventional learning media to digital learning. It can be seen from the number of lecturers who give assignments through digital platforms (Liansari \& Nuroh, 2018). In practice, students utilized digital devices to develop their speaking and listening skills by accessing YouTube or podcasts. Students would prefer to exercise podcasts to recordings of teachers to improve listening and speaking skills. Top et al., (2006) argues that podcasts can be used as additional material besides those available from textbooks, learning resources to promote listening skills, and as a way for students to obtain information about aspects of language idioms, grammar, or expressions. In addition, Knight, in her study, reported that students tend to listen to a podcast repeatedly due to its potential values to increase students' confidence in phonetics ability (Knight, 2010). This finding is supported by Bustari et al. In their experimental research; it reported that there was a significant improvement of the 
students' oral test performance after undertaking treatments using podcast (Bustari et al., 2017).

On the other hand, students reported that they accessed Google Translate to find unfamiliar vocabularies. Google translate has been claimed to be able to facilitate students deal with their difficulties, such as to understand texts, recall and retrieve difficult words and grammatical structures or to complete difficult tasks in the classroom (Karimian \& Talebinejad, 2013). Similarly, another prior study highlighted that Google Translate provides significantly better quality writing than studentgenerated text, by having more words, fewer errors in spelling and grammar, and fewer errors per word. A follow-up questionnaire survey showed that EFL students find satisfaction using Google Translate in their written English, especially in finding vocabulary and improving English written completion (Tsai, 2019). This great prospective influenced students to employ Google translate into learning.

To find valid and reliable information, students tend to compare and evaluate various sources concerning finding and selecting reliable information, and this ability was categorized to information literacy (Eshet, 2004). Fabos (2004) argues that students' critical thinking skills can be increased effectively by a comparative approach. Students are considered to find an objective truth to the information received by processing a thorough evaluation and comparison information from various sources. Hague \& Payton (2010) also noted that students need to be motivated to think carefully about finding reliable information and using resources obtained through the internet selectively to help them make arguments or do an activity. Meanwhile, another student relied on data from a trusted source; reputable course institutions' websites or educational sites are the most frequently preferred sites because they are considered more credible. This finding supported with previous research that revealed that almost all students of California state university begin the information search by trying to find an outline (essential points) of the available information, identify information relevant to the topic assigned to them, then students investigate and evaluate the information. Most students even first look for information from websites, databases, and books and send emails to people they think might have information relevant to their topic (Dunn, 2002). In addition, teacher recommendations about the site that can be used as a learning source were also considered a practical step for students to avoid getting inaccurate or insecure information. As Payton \& Hague (2010) suggested, teachers can give information about how to construct the web search so that the students are more likely to find relevant information.

On the other hand, digital literacy was also integrated into learning activities to create new work from existing products. In practice, students utilized the Canva application to design and to build a brochure complete with information in text and images. This activity offers opportunities for students to interpret and understand the information presented in illustrations and develop student creativity. The ability to interpret and understand the information presented in pictures is known as photo-visual literacy (Eshet, 2004). Similar to this study, previous studies which stated that the pre-service 
teachers' skills in interpreting, understanding, and appreciating the meaning of visual messages were enhanced through online exchange and interaction employing photo management and sharing applications. They were able to communicate more effectively by applying the basic principles and concepts of visual design (Sadik, 2011). In short, the findings suggest that students tend to connect digital literacy within their activities in using digital tools. This finding is supported by Vrana (2014). The study claimed that students connect the concept of digital literacy most frequently with multimedia and editing different digital content types and writing text by including (citing/using) other information resources. This coincides with Dudeney and Hockly (2016) in Farr \& Murray (2016) which noted that students could obtain digital literacy as part of language learning through activities and assignments that combine technology.

Based on the observation, it highlighted that the technology-based project given by the teacher promote students' digital literacy (Perdana et al., 2019) and the frequency of the integration of digital literacy competencies. Due to the brochure project, the learners frequently integrate photo-visual literacy. The project required them to understand, interpret, and create information which is given with the pictures and graphics. In terms of designing, learners employed an online platform which provided template and tools in the form of icons and symbols to facilitate the users designing their brochure. Similarly, Shivers (2017) argued that incorporating works of art and visual literacy skills stimulate higher school students' perception and idea production.

Another competency of digital literacy that was often integrated by students in learning activities was information literacy. Creating a brochure project offered students to collect the sample of a brochure, gather the information about a place or job and images that were appropriate as much as they can. The collected information had to be valid and reliable to avoiding misinformation. It required them to polish their information literacy and critical thinking ability; analyzing, assessing, distinguishing and utilizing the collected information. Along with this study, Zapalska et al., (2018) in their research claims that giving assignments to Management Coursework's students requires them to find, select, assess, and apply information drawn from various libraries and internet resources. After completing a report or assignment, students not only gain knowledge but also master information literacy skills.

The last marked part was reproduction literacy. The final goal of the brochure project was that the students were able to produce a brochure which was completed with reliable information and images. To reach this goal, the students prefer to employ online applications that are provided with existing templates that can be adjusted according to student creativity. This finding is in line with Ozdamar-Keskin et al., (2020) which report that Anadolu University students prefer to use visual learning platform. 


\section{CONCLUSION}

This study provided insight that current students can be categorized as digitally literate. In this case, students are able to use technology to assist them in learning, understand the information presented in text or illustration, and select information according to their needs. In every interaction with the internet or other digital tools, students always integrate their survival skills. Students tend to integrate digital literacy according to the activities and objectives to be achieved. For example, in searching and understanding information, students integrate the ability of photo-visual literacy to obtain information presented in the form and information literacy to select valid information and reproduction literacy to make a product. These three digital literacy competencies are also the most frequently observed in students' teaching and learning activities. At the same time, other competencies such as branching literacy exist but are not too prominent. For the ability of socio-emotional literacy and real-time thinking skills, it seems to be easier to observe when students use social media.

\section{REFERENCES}

Akayoğlu, S., Satar, H. M., Dikilitaş, K., Cirit, N. C., \& Korkmazgil, S. (2020). Digital literacy practices of Turkish pre-service EFL teachers. Australasian Journal of Educational Technology. https://doi.org/10.14742/ajet.4711

Bekker, T., Bakker, S., Douma, I., van der Poel, J., \& Scheltenaar, K. (2015). Teaching children digital literacy through design-based learning with digital toolkits in schools. International Journal of Child-Computer Interaction. https://doi.org/10.1016/j.ijcci.2015.12.001

Bustari, A., Samad, I. A., \& Achmad, D. (2017). The use of podcasts in improving students' speaking skill. JELE (Journal of English Language and Education). https://doi.org/10.26486/jele.v3i2.256

Creswell, J. W. (2007). Qualitative enquiry \& research design, choosing among five approaches. In Book.

Dunn, K. (2002). Assessing information literacy skills in the California State University: A progres report. Journal of Academic Librarianship. https://doi.org/10.1016/S0099-1333(01)00281-6

Eshet-Alkalai, Y. (2012). Thinking in the Digital Era: A Revised Model for Digital Literacy. Issues in Informing Science and Information Technology. https://doi.org/10.28945/1621

Eshet, Y. (2004). Digital Literacy: A Conceptual Framework for Survival Skills in the Digital era. Journal of Educational Multimedia and Hypermedia.

Fabos, B. (2004). Giddy Prophesies and Commercial Ventures: The History of Educational Media. In Wrong Turn on the Information Superhighway: Education and the Commercialization of the Internet.

Farr, F., \& Murray, L. (2016). The routledge handbook of language learning and technology. In The Routledge Handbook of Language Learning and Technology. https://doi.org/10.4324/9781315657899 
Gilster, P. (1997). Digital literacy. N.Y: Wiley Computer Publishing

Hafner, C. A. (2014). Embedding Digital Literacies in English Language Teaching: Students' Digital Video Projects as Multimodal Ensembles. TESOL Quarterly. https://doi.org/10.1002/tesq. 138

Hague, C., \& Payton, S. (2010). Digital literacy across the curriculum Key to themes: A Futurelab handbook. Futurelab.

Karimian, Z., \& Talebinejad, M. R. (2013). Students' Use of Translation as a Learning Strategy in EFL Classroom. Journal of Language Teaching and Research. https://doi.org/10.4304/j1tr.4.3.605-610

Knight, R.-A. (2010). Sounds for Study: Speech and Language Therapy Students' Use and Perception of Exercise Podcasts for Phonetics. International Journal of Teaching and Learning in Higher Education.

Kurnia, N., \& Astuti, S. I. (2017). Peta Gerakan Literasi Digital Di Indonesia: Studi Tentang Pelaku, Ragam Kegiatan, Kelompok Sasaran Dan Mitra Yang Dilakukan Oleh Japelidi. Informasi. https://doi.org/10.21831/informasi.v47i2.16079

Kurniawati, N., Maolida, E. H., \& Anjaniputra, A. G. (2018). The praxis of digital literacy in the EFL classroom: Digital-immigrant vs digital-native teacher. Indonesian Journal of Applied Linguistics. https://doi.org/10.17509/ijal.v8i1.11459

Liansari, V., \& Nuroh, E. Z. (2018). Realitas Penerapan Literasi Digital bagi Mahasiswa FKIP Universitas Muhammadiyah Sidoarjo. Proceedings of the ICECRS. https://doi.org/10.21070/picecrs.v1i3.1397

Martin, A. (2005). DigEuLit - a European Framework for Digital Literacy: a Progress Report. Journal of ELiteracy.

Meyer, K. A. (2002). Quality in Distance education: Focus on On-Line Learning. ASHE-ERIC Higher Education Report (A. J. Kezar (ed.)). Jossey-Bass. https://files.eric.ed.gov/fulltext/ED470042.pdf

Miles, M. B., Huberman, A. M., \& Saldana, J. (2014). Qualitative Data Analysis: A Methods Sourcebook. Third Edition. In The SAGE Handbook of Applied Social Research Methods.

Ozdamar-Keskin, N., Ozata, F. Z., Banar, K., \& Royle, K. (2020). Examining Digital Literacy Competences and Learning Habits of Open and Distance Learners. Contemporary Educational Technology, 6(1), 74-90. https://doi.org/10.30935/cedtech/6140

Payton, S., \& Hague, C. (2010). Digital Literacy Professional Development Resource. Development.

Perdana, R., Yani, R., Jumadi, J., \& Rosana, D. (2019). Assessing Students' Digital Literacy Skill in Senior High School Yogyakarta. JPI (Jurnal Pendidikan Indonesia). https://doi.org/10.23887/jpi-undiksha.v8i2.17168

Porat, E., Blau, I., \& Barak, A. (2018). Measuring digital literacies: Junior high-school students' perceived competencies versus actual performance. Computers and Education. https://doi.org/10.1016/j.compedu.2018.06.030

Prensky, M. (2001). Digital Natives, Digital Immigrants Part 1. On the Horizon. 
https://doi.org/10.1108/10748120110424816

Puspito, D. W. (2017). Implementasi Literasi Digital Dalam Gerakan Literasi Sekolah. Konferensi Bahasa Dan Sastra (International Conference on Language, Literature, and Teaching) II.

Sadaf, A., \& Johnson, B. L. (2017). Teachers' Beliefs About Integrating Digital Literacy Into Classroom Practice: An Investigation Based on the Theory of Planned Behavior. Journal of Digital Learning in Teacher Education. https://doi.org/10.1080/21532974.2017.1347534

Sadik, A. (2011). Improving pre-service teachers' visual literacy through online photosharing applications. International Journal of Emerging Technologies in Learning. https://doi.org/10.3991/ijet.v6i1.1360

Shivers, J. C. M. (2017). Visual Literacy, Creativity and the Teaching of Argument. Learning Disabilities: A Contemporary Journal.

Solikhati, H. A., \& Pratolo, B. W. (2019). The Implementation of Digital Literacy in EFL Learning: A Case Study in SMP Muhammadiyah 1 Temanggung. http://eprints.uad.ac.id/id/eprint/14803

Thorne, S. L., \& Reinhardt, J. (2008). Bridging activities, new media literacies, and advanced foreign language proficiency. CALICO Journal. https://doi.org/10.1558/cj.v25i3.558-572

Top, T., Top, T., Stanley, G., Stanley, G., British, T., British, T., Barcelona, C., Barcelona, C., Richardson, W., \& Richardson, W. (2006). Podcasting: Audio on the Internet Comes of Age. Notes.

Tsai, S. C. (2019). Using google translate in EFL drafts: a preliminary investigation. Computer Assisted Language Learning. https://doi.org/10.1080/09588221.2018.1527361

Vrana, R. (2014). Digital literacy as a prerequisite for achieving good academic performance. Communications in Computer and Information Science. https://doi.org/10.1007/978-3-319-14136-7_17

Zapalska, A. M., McCarty, M., Young-McLear, K., Zieser, N., Kelley, T., \& Glinski, M. (2018). The Integration of Information Literacy Assignments within the Management Coursework as a Strategy for Development of Students' Independent Learning and Lifelong Learning Skills. Literacy Information and Computer Education Journal, 9(4), 3002-3017. https://doi.org/10.20533/licej.2040.2589.2018.0394 